ISSN (Online) 2710-3315

https://doi.org/10.20535/EHS.2021.233527

УДК 628.17

\title{
УТИЛІЗАЦІЯ РЕГЕНЕРАЦІЙНИХ РОЗЧИНІВ, ЩО МІСТЯТЬ ІОНИ АМОНІЮ РЕАГЕНТНИМ МЕТОДОМ
}

\author{
О.В. Глушко \\ Національний технічний університет України \\ "Київський політехнічний інститут ім. Ігоря Сікорського" \\ пр. Перемоги, 37, Київ, 03056, Україна \\ e-mail: alyona_glushko@ukr.net
}

Проблема захисту навколишнього середовища від антропогенного впливу $є$ однією 3 найважливіших на сьогоднішній день. Одним з головних напрямків в охороні навколишнього середовища та раціонального використання природних ресурсів вважається утилізація i знешкодження стічних вод та відходів гальванічних виробництв. Широке впровадження замкнутих систем водопостачання на гальванічних виробництвах дозволяє попередити скид важких металів в довкілля. У зв'язку 3 цим, велика увага приділяється розробці та впровадженню технологій очистки води, котрі не призводять до збільшення ії сольового складу та дозволяють утилізувати корисні речовини. 3 цієї точки зору іонний обмін [1] $€$ найбільш перспективним методом очистки.

При іонообмінному очищенні води головною проблемою $є$ утворення значних об'ємів регенераційних розчинів. В результаті регенерації іонітів отримують концентровані кислі або лужні розчини солей металів, які досить складно утилізувати. Слід зазначити, що іонообмінна очистка стічних вод вибирається в тому випадку, коли доводиться мати діло із порівняно невеликими об'ємами стоків 3 досить простим хімічним складом. Головною ж перешкодою до поширення іонного обміну в практиці очистки стічних вод від важких металів $є$ недостатня ефективність та недосконалість процесів регенерації іонообмінних матеріалів та складність переробки отриманих розчинів.

Відомо, що катіоніт КУ-2-8 добре регенерується від іонів важких металів розчинами солей амонію [2]. Аміак і його солі належать до досить шкідливих для довкілля сполук. ГДК на скид у каналізацію м. Києва становить 2.0 г/м ${ }^{3}$ [3]. Тому важливим $є$ питання утилізації регенераційних розчинів.

Переробка таких амонійвмісних регенераційних розчинів може бути здійснена різними методами, кожен з яких має свої переваги та недоліки. Серед найбільш актуальних методів вилучення іонів амонію 3 водних розчинів безперечно $є$ біологічні [4], сорбційні [5], електрохімічні [6]. Проте для вилучення іонів амонію із водних розчинів, що характеризуються високими концентраціями іонів амонію ефективними залишаються реагентні методи.

Одним 3 простих методів є видалення іонів амонію у вигляді малорозчинної сполуки магнійамонійфосфату (МАФ) $\mathrm{MgNH}_{4} \mathrm{PO}_{4} \cdot 6 \mathrm{H}_{2} \mathrm{O}$. За оцінками спеціалістів, вартість такої системи у сім разів менша за традиційні [7]. Але через невизначеність оптимальних умов кристалізації МАФ у водних розчинах, ці системи не набули широкого розповсюдження. 
Метою роботи було дослідження впливу різноманітних факторів на процес кристалізації МАФ.

На першому етапі досліджень вивчався вплив рН на процес кристалізації МАФ. Вихідна концентрація іонів амонію в досліджуваних розчинах становила 336 мг/л. Попередніми дослідженнями було встановлено, що при додаванні реагентів, розрахованих виходячи зі складу МАФ, процес кристалізації проходить досить повільно. Тому в першій серії дослідів додавали подвійну дозу іонів магнію та фосфат-аніонів. $\mathrm{pH}$ встановлювали 3 допомогою гідроксиду натрію в межах від 7 до 12. Початкова концентрація іонів амонію - 336 мг/дм³. Суміш відстоювали протягом трьох годин, відфільтровували та визначали вміст іонів амонію у фільтраті. Температура досліду становила $23{ }^{\circ} \mathrm{C}$. Результати досліджень показали, що ефективність виділення іонів амонію в діапазоні $\mathrm{pH}$ 7-12 суттєво не змінюється і коливається в межах 55-77 \%. Зі зміною рН суттєво змінюється об'єм осаду. При рН більше 9 вода в пробах не освітлюється при відстоюванні навіть протягом трьох годин. Осад погано ущільнюється. Аналіз, проведений в тих самих пробах через дві доби, показав, що залишкові концентрації амонію знизились у декілька разів. Вода у всіх пробах освітлилась. Найменший об'єм осаду утворився при $\mathrm{pH}$ 8.9. При $\mathrm{pH}$ менших і більших вказаного діапазону утворюється аморфний осад збільшеного об'єму.

На наступному етапі досліджень визначали вплив температури на процес кристалізації МАФ. Методика проведення досліду не відрізнялась від описаної вище. Лише постійним підтримувалося $\mathrm{pH}$ на рівні 9, а змінним параметром була температура.

За результатами досліджень в діапазоні температур від 20 до $60{ }^{\circ} \mathrm{C}$ не було встановлено однозначної залежності. Очевидно це пов'язане з тим що при різних температурах формується МАФ різного складу [8]. Якщо проводити процес при $20{ }^{\circ} \mathrm{C}$ у розчині формується магнійамонійфосфат складу $-\mathrm{MgNH}_{4} \mathrm{PO}_{4} \cdot 6 \mathrm{H}_{2} \mathrm{O}$, а при $30{ }^{\circ} \mathrm{C}-\mathrm{MgNH}_{4} \mathrm{PO}_{4} \cdot 5 \mathrm{H}_{2} \mathrm{O}$, при $50-70{ }^{\circ} \mathrm{C}$ $-\mathrm{MgNH}_{4} \mathrm{PO}_{4} \cdot 3 \mathrm{H}_{2} \mathrm{O}$.

Крім цього, температура впливає на стан самого осаду. Було визначено, що з технологічної точки зору найбільш доцільно нагрівати розчини до $50{ }^{\circ} \mathrm{C}$, що забезпечить найменші залишкові концентрації, найшвидше освітлення та найменший об'єм осаду.

Очевидно, що суттєво на процес утворення осаду МАФ у водному розчині впливає його склад та співвідношення між компонентами. На рис.1 приведені залишкові концентрації іонів амонію при введенні надлишкових доз оксиду магнію, фосфорної кислоти або одночасно оксиду магнію і фосфорної кислоти по відношенню до стехіометрії $\mathrm{N}_{\text {ст. }}$

Як видно з даних рис.1, додавання в розчин надмірної кількості оксиду магнію при постійній стехіометричній кількості фосфат-іонів не супроводжується суттєвим зниженням залишкових концентрацій іонів амонію, а при значному надлишку навіть збільшується. При збільшенні дози фосфат-іонів залишкові концентрації $\mathrm{NH}_{4}^{+}$знижується. Можливо це пов'язано з тим, що при збільшенні дози кислоти, зменшується рН вихідного розчину, що збільшує концентрацію іонів магнію, які дозуються у вигляді $\mathrm{MgO}$. При одночасному збільшенні дози оксиду магнію і кислоти спостерігається стабільне зниження залишкових концентрацій іонів амонію. Проте, збільшення кількості доз вище ніж у три рази недоцільно 3 точки зору використання реагентів і об'єму осаду, який суттєво збільшується, не супроводжуючись відповідним збільшенням ефективності видалення іонів амонію.

\footnotetext{
Handbook of the XXII International Science Conference «Ecology. Human. Society» (2021 Kyiv, Ukraine)
} 


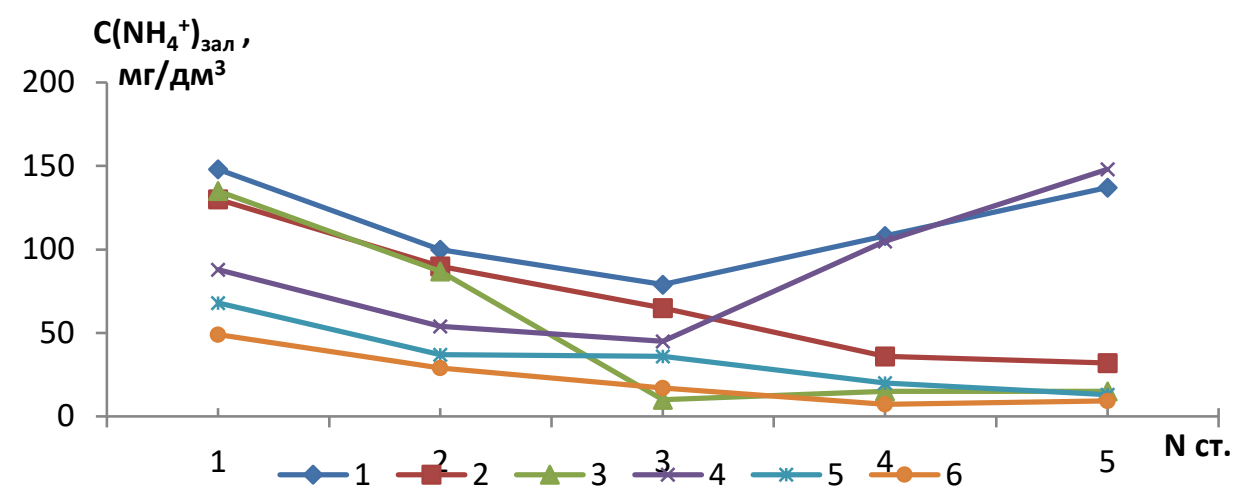

Рисунок. Залежність залишкових концентрацій іонів амонію від надлишку доз реагентів по відношенню до стехіометрії $\mathrm{N}_{\text {ст: }} 1,4$ - надлишок MgO; 2,5 - надлишок НзРО4; 3,6- надлишок МgО та НзРО4 та часу взаємодії:1,2,3- дві години; 4,5,6 - дві доби

Також були проведені дослідження впливу початкових концентрацій іонів амонію на ефективність їх видалення з водних розчинів. Було встановлено, що найбільш раціонально використовувати даний метод в діапазоні початкових концентрацій іонів амонію 50-5000 мг/дм³ ${ }^{3}$ При низьких початкових концентраціях спостерігалась недостатня ефективність методу, а при значних - високі залишкові концентрації.

Отже, проведені дослідження показали, що використання методу кристалізації МАФ дає можливість знизити концентрацію іонів амонію в стічних водах. Найбільш придатними параметрами проведення процесу кристалізації $є$ : $\mathrm{pH}$ 8-9, температура - $50{ }^{\circ} \mathrm{C}, 2-3$ кратна доза реагентів, початкова концентрація у діапазоні 50-5000 мг/дм³ .

\section{Література:}

1. Fu F., Wang Q. Removal of heavy metal ions from wastewaters: A review, Journal of Environmental Management. No 92, pp. 407 - 418, 2011.

2. Liberti L., Laricchinta A., Lopez A. The RIMNUT process at West Bari for removal of nutrients from wastewater: second demonstration, Resour.and Conserv. Vol.15, No. 1-2, pp.95-111,1987.

3. Правила приймання стічних вод підприємств у систему каналізації м. Києва. - К.: Київська міська державна адміністрація, 2003. - 16 с.

4. Вембер В. В. Інтенсифікація біологічних процесів при вилученні з води іонів амонію / В. В. Вембер, М. Д. Гомеля, А. І. Петриченко // Вісник національного технічного університету України «Київський політехнічний інститут». Серія «Хімічна інженерія, екологія та ресурсозбереження». - 2017. - № 1 (16). - С. 53 - 58. - Режим доступу: http://chemengine.kpi.ua/article/ view/119472/114017.

5. Макаренко И. Н. Исследование эффективности сорбционной очистки воды от ионов аммония на природных и искусственных сорбентах / И. Н. Макаренко, И. Н. Трус, А. И. Петриченко, А. Ю. Кийченко // Энерготехнологии и ресурсосбережение. - 2017. - № 3. - С. 42 $-48$.

6. Гомеля М. Д. Вилучення іонів амонію з води електролізом // М. Д. Гомеля, А. І. Петриченко, Т. О. Шаблій // Вчені записки Таврійського Національного Університету імені В. I. Вернадського. Серія «Технічні науки». - 2018. - №4 (68). - С. 99 - 105. - Режим доступу: http://www.tech.vernadskyjournals.in.ua/journals/2018/4_2018/part_2/20.pdf.

7. High-efficiency, low-cost collection of nitrogen and phosphorus from wasterwater,Technol.Jap, Vol.21, No. 4, pp.112-120,1988.

8. Щегров Л.Н. Фосфати двухвалентных металлов. - Киев : Наук. думка, 1987. - 216 с. 